\title{
Interesterification of Engkabang (Shorea macrophylla) Fat - Canola Oil Blend with Lipase from Candida antarctica to Simulate the Properties of Lard
}

\author{
Nur Illiyin Mohamed Roslan ${ }^{1}$, Jalaldeen Mohamed Nazrim Marikkar ${ }^{1,2 *}$, \\ Loke Mei Key ${ }^{2}$, Shuhaimi Musthafa ${ }^{1}$, Mahiran Basri ${ }^{1}$ and Miskandar Mat Saari ${ }^{3}$ \\ ${ }^{1}$ Halal Products Research Institute, Universiti Putra Malaysia, 43400 UPM Serdang, Selangor D. E., Malaysia \\ ${ }^{2}$ Department of Biochemistry, Universiti Putra Malaysia, 43400 UPM Serdang, Selangor D. E., Malaysia and ${ }^{3}$ Malaysian Palm Oil Board, No. 6 \\ Persiaran Institusi, Bandar Baru Bangi, 43000 Kajang, Selangor D. E., Malaysia
}

\begin{abstract}
A study was carried out to compare the composition and thermal properties of lard (LD) and engkabang fat (EF) - canola oil (CaO) blend interesterified with $C$ andida antartica lipase $(C$. antartica). A fat blend EF-4 (40\% EF in CaO) was prepared and interesterified using $C$. antartica lipase at $60^{\circ} \mathrm{C}$ for different time intervals $(6 \mathrm{~h}, 12 \mathrm{~h}$ and $24 \mathrm{~h})$ with $200 \mathrm{rpm}$ agitation. The fat blends before and after interesterification were compared to LD with respect to their slip melting points (SMP), fatty acid and triacyglycerol (TAG) compositions, melting, solidification and polymorphic properties. Result showed that the slip melting point (SMP) of the fat blend interesterified for $6 \mathrm{~h}$ was the closest to that of LD. The solid fat content (SFC) values of fat blends interesterified for 12 and $24 \mathrm{~h}$ were found to become equal to those of LD within the temperature range of 0 to $20^{\circ} \mathrm{C}$. In addition, all three interesterified blends had SFC values similar to those of $L D$ within the temperature range of $30-40^{\circ} \mathrm{C}$. According to thermal analysis, the transition of the fat blend interesterified for $24 \mathrm{~h}$ appearing at $-2.39^{\circ} \mathrm{C}$ was similar to the low melting thermal transition of LD and the transition of the fat blend interesterified for $12 \mathrm{~h}$ appearing at $26.25^{\circ} \mathrm{C}$ was similar to the high melting thermal transition of LD. However, there is no compatibility between LD and all three interesterified blends with regard to polymorphic behaviour.
\end{abstract}

Key words: canola oil, engkabang fat, interesterified blend, lard alternative, thermal behaviour, Shorea macrophylla

\section{INTRODUCTION}

Food taboos are prohibitive food practices arising due to religious and cultural restrictions. Across the globe, most cultures practise some form of food taboos with or without a proper basis ${ }^{1)}$. A well-known food taboo is the prohibition against eating of pork. According to Jewish and Muslim believes, swine is considered as unclean and eating of its flesh or any product derived from the animal is prohibited ${ }^{2)}$. However, production of pork is a worldwide business since pork consumption is an important component of diet in many parts of the world. Among the leading producers, the United States, the European Union, and Canada contribute more than $70 \%$ of the world demand for pork ${ }^{3)}$. As swine is also an animal rich in lipids, production of lard is recognized as important revenue for the swine carcass industry $^{4}$. Historically, lard has been used as a useful raw material for food and other industrial applications. For instance, it has been used in the manufacture of oleomargarine, jellies, bakery shortening and cooking fats ${ }^{5}$. However, inclusion of lard in food and other consumer products is a serious concern for Jewish and Muslim religious practices ${ }^{2)}$. Aside this, consumption of animal fats including lard is not recommended because of negative perceptions about the implications of animal fats on human health ${ }^{6}$. Consequently, there is a growing interest to find some alternative fat source as substitute to replace the use of lard in food formulations.

As lard is a semi-solid fat, the fat blend simulating the properties of lard may be prepared by blending different plant-based fats and oils. The effort on blending of plant fats and oils to produce an alternative fat for lard is still limited to few studies. In the past, researchers mainly focused their attention to evaluate various plant fats for

*Correspondence to: J. M. N. Marikkar, Halal Products Research Institute, Universiti Putra Malaysia, 43400 UPM Serdang, Selangor D. E., Malaysia

E-mail: nazrim_marikkar@upm.edu.my

Accepted September 6, 2013 (received for review July 24, 2013)

Journal of Oleo Science ISSN 1345-8957 print / ISSN 1347-3352 online

http://www.jstage.jst.go.jp/browse/jos/ http://mc.manusriptcentral.com/jjocs 
partial substitution of lard in various products ${ }^{7-10)}$. However, none of these previous studies have considered the complete replacement of lard with a fat blend equivalent in thermal properties. In a recent study, Nur Illiyin and co-workers ${ }^{11)}$ found that blending of Engkabang fat from the seeds of Shorea macrophylla with canola oil could provide a potential oil mixture to simulate the thermal properties of lard. Among the different fat blends investigated, the physical properties of some blends could be further improved through enzymatic interesterification using lipase from $C$. antartica $^{12}$. Hence, the objective of this study was to compare the composition and physical properties of the interesterified blends of EngkabangCanola fat with lard using GC, HPLC, DSC, NMR, and X-ray diffraction techniques.

\section{EXPERIMENTAL}

\subsection{Materials}

LD was extracted using three batches of adipose tissues of swine collected from local slaughter houses according to the method reported previously by Marikkar et al. ${ }^{13)}$. Dried seeds of 'Engkabang Jantong' (Shorea macrophylla) were collected from three different locations in Sarawak, Malaysia. Samples of $\mathrm{CaO}$ (Sime Darby Food Marketing Sdn Bhd, Selangor, Malaysia) were purchased from a supermarket in Malaysia. Lipase from C. antartica (Novozym 435) was purchased from Sigma Aldrich. All chemicals used in this study were of analytical or HPLC grade.

\subsection{Extraction of EF and preparation of binary blends}

Fat extraction from finely ground samples of dried Engkabang seeds was carried out via the soxhlet extraction method using petroleum ether (b.p. 40-60 ${ }^{\circ} \mathrm{C}$ ) for $8 \mathrm{~h}^{14)}$. The extracted fat was used for the preparation of binary blends after expelling solvent under reduced pressure using a rotatory evaporator system. A blend of Engkabang-canola oil (EF-4) was prepared by mixing EF to $\mathrm{CaO}$ in $40: 60(\mathrm{w} / \mathrm{w})$ and left under frozen storage at $-20^{\circ} \mathrm{C}$ until the time of analysis. Prior to analyses, EF, $\mathrm{LD}, \mathrm{CaO}$, and EF-4 were removed from frozen storage, and then left static at room temperature for $1 \mathrm{~h}$ before being warmed at $60^{\circ} \mathrm{C}$ until they became completely molten.

\subsection{Enzymatic interesterification}

Enzymatic interesterification of EF-4 $(40 \mathrm{~g})$ was carried out in a solvent-free system using Novozym $435(1 \%$, w/w oil). The reaction mixtures in triplicate were subjected to 6 $\mathrm{h}, 12 \mathrm{~h}$ and $24 \mathrm{~h}$ of agitation separately in orbital shakers at $200 \mathrm{rpm}$ and $60^{\circ} \mathrm{C}$. At the end of the reaction, the product samples were removed from the reaction mixture via hot filtration using a Whatman No. 1 filter paper ${ }^{15}$.

\subsection{Determination of slip melting point (SMP) and free fatty acid content (FFA \%)}

SMP and FFA (\%) of the oil/fat samples was determined according to AOCS method Cc.3.25, and AOCS Method Ca $5 a-40$, respectively ${ }^{16)}$.

\subsection{GLC analysis of fatty acid methyl esters (FAME)}

FAME were prepared by dissolving $50 \mathrm{mg}$ portion of the oil in $0.8 \mathrm{ml}$ of hexane and adding $0.2 \mathrm{ml}$ portion of $1 \mathrm{M} \mathrm{so-}$ lution of sodium methoxide ${ }^{17)}$, and then analyzed on a gas chromatograph (Agilent Technologies, Singapore) fitted with an FID detector. The polar capillary column DB-wax (with $0.25 \mathrm{~mm}$ internal diameter, $30 \mathrm{~m}$ length and $0.25 \mu \mathrm{m}$ film thickness; Agilent Technology, Santa Clara, CA) was used. The oven temperature was programmed as follows: initial temperature of $50^{\circ} \mathrm{C}$ (for $1 \mathrm{~min}$ ), programmed to increase to $200^{\circ} \mathrm{C}$ at $8^{\circ} \mathrm{C} / \mathrm{min}$. Both injector and detector temperatures were maintained at $200^{\circ} \mathrm{C}$ throughout the analysis. The carrier gas (helium) flow rate was $1.0 \mathrm{~mL} / \mathrm{min}$ and the split ratio was 58:1. Identification of the peaks was done with reference to a chromatographic profile containing 37 FAME standards (Supelco, Bellefonte, PA). The percentage of fatty acid was calculated as the ratio of the partial area to the total peaks area ${ }^{111}$.

\subsection{HPLC analysis of TAG composition}

The TAG composition was determined using a Waters Model 2695 liquid chromatograph equipped with a differential refractometer Model 2414 as a detector(Waters Associates, Milford, MA). The TAG separation was performed on a Merck LiChrospher RP-18 column ( $5 \mu \mathrm{m}$ particle size, L $\times$ I.D. $25 \mathrm{~cm} \times 3.2 \mathrm{~mm}$ ) . The mobile phase was a mixture of acetone: acetonitrile (63.5:36.5), and the flow rate was $1.5 \mathrm{~mL} / \mathrm{min}$. The column temperature was maintained at $30^{\circ} \mathrm{C}$. The injector volume was $10 \mu \mathrm{L}$ of $5 \%(\mathrm{w} / \mathrm{w})$ oil in chloroform. Each sample was chromatographed three times, and the data was recorded as area percentages ${ }^{11}$. The identification of TAG peaks of samples was done using a set of TAG standards purchased from Sigma-Aldrich (Deisehofen, Germany) as well as the TAG profiles of lard ${ }^{18)}$, Engkabang fat ${ }^{11)}$, and canola oil ${ }^{19)}$ as reported previously.

\subsection{Thermal analyses by DSC}

Thermal analysis was carried out on a Mettler Toledo differential scanning calorimeter(DSC 823 Model), equipped with a thermal analysis data station (STARe software, Version 9.0x, Schwerzenbach, Switzerland). Before the analysis, calibration of the instrument was done using Indium as the metallic standard, based on the onset temperature of fusion and the heat of fusion of indium. Nitrogen (99.99\% purity) was used as the purge gas at a rate of $20 \mathrm{~mL} / \mathrm{min}$. Approximately 4-8 $\mathrm{mg}$ of molten sample was placed in a standard DSC aluminum pan and then her- 
metically sealed. An empty and hermetically sealed DSC aluminum pan was used as the control. The oil/fat samples were subjected to the following temperature program: $70^{\circ} \mathrm{C}$ isotherm for $1 \mathrm{~min}$, cooled at $5^{\circ} \mathrm{C} / \mathrm{min}$ to $-70^{\circ} \mathrm{C}$. The samples were held at $-70^{\circ} \mathrm{C}$ isotherm for $1 \mathrm{~min}$, and heated at $5^{\circ} \mathrm{C} / \mathrm{min}$ to reach $70^{\circ} \mathrm{C}^{11)}$.

\subsection{Determination of solid fat content (SFC) by NMR}

$\mathrm{SFC}$ was measured according to AOCS method Cd 16b$93^{16)}$ using a Bruker Minispec (Model Mq 20) pulse Nuclear Magnetic Resonance (pNMR) spectrometer (Karlsruhe, Germany). Before the analysis, the instrument was calibrated using $0 \%, 31.2 \%$ and $72.1 \%$ solid SFC calibration standards. The sample in the NMR tube was melted at $70^{\circ} \mathrm{C}$ for $15 \mathrm{~min}$, followed by chilling at $0^{\circ} \mathrm{C}$ for $60 \mathrm{~min}$, and then held at each measuring temperature for $30 \mathrm{~min}$ prior to measurement. Melting, chilling and holding of the samples were carried out in pre-equilibrated thermostated glycol containing baths, accurate to $0.1^{\circ} \mathrm{C}$. SFC measurements were taken in duplicate at $5{ }^{\circ} \mathrm{C}$ intervals over a range of $0-55^{\circ} \mathrm{C}$.

\subsection{X-ray diffraction analysis}

The polymorphic forms of fat crystals were determined using a wide angle X-ray diffraction (WAXD) machine(D8 Advance Bruker AXS, Karlsruhe, Germany). Before analysis, samples were melted at $70^{\circ} \mathrm{C}$ for $10 \mathrm{~min}$, followed by chilling at $4^{\circ} \mathrm{C}$ for $24 \mathrm{~h}$, and then held at $25^{\circ} \mathrm{C}$ for $30 \mathrm{~min}$. The power used was $40 \mathrm{kv}, 40 \mathrm{~mA}$ with the source of beam from $\mathrm{Cu}$ K $\alpha 1$ X-ray beam $(\lambda=0.15406 \AA)$. The samples were scanned from $15^{\circ} 2 \theta$ to $25^{\circ} 2 \theta$, increasing with a step size of $0.025^{\circ} / 0.1 \mathrm{sec}^{20)}$. Short spacing on the X-ray film was measured with an Evaluation Diffract plus software. The short spacings of the $\beta^{\prime}$ form were at 4.2 and $3.8 \AA$ while that of the $\beta$ form was at $4.6 \AA^{211}$.

\subsection{Statistical analysis}

All results from analyses were expressed as the mean value \pm standard deviation. Data were statistically analysed by one-way analysis of variance (ANOVA) using Tukey's test of MINITAB (version 14) statistical package at 0.05 probability level.

\section{RESULTS AND DISCUSSION}

\subsection{SMP}

SMP of LD, EF, CaO, EF-4 and its interesterified blends are given in Table 1. The SMP of EF was $34.5^{\circ} \mathrm{C}$ while that of the physical blend EF- 4 was $31.2^{\circ} \mathrm{C}$. As shown in Table 1, all three interesterified blends melted at lower temperatures and possessed relatively higher contents of FFA(\%) than the corresponding physical blend. As the interesterification time varied from 6 to $24 \mathrm{~h}$, a declining trend in SMP

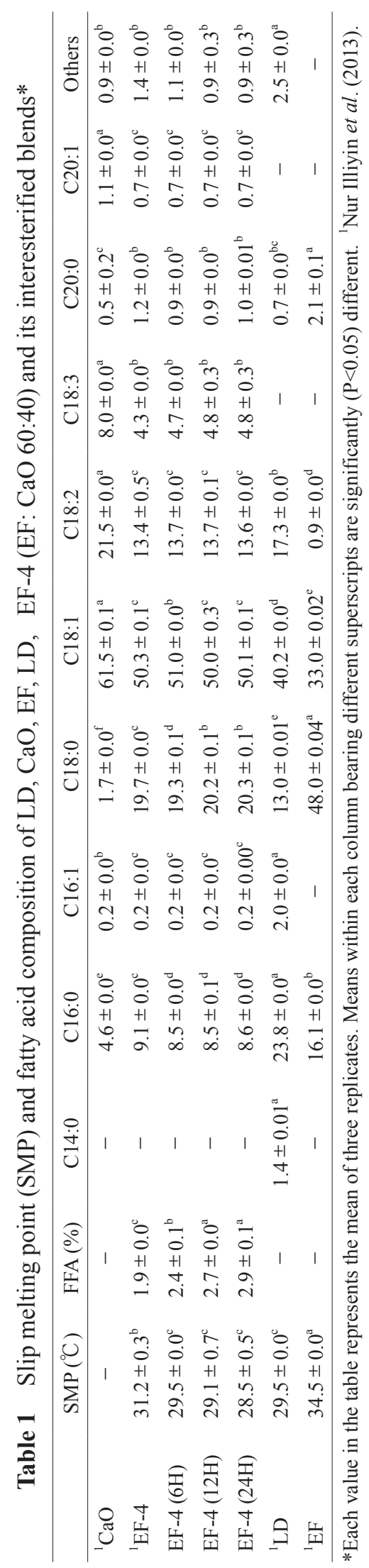


as well as an increasing of $\mathrm{FFA}(\%)$ contents of fat blends was noticed. Of the three interesterified blends, EF-4(6h) showed a SMP value closely comparable to that of LD $\left(29.5^{\circ} \mathrm{C}\right)$. The decrease in SMP could be due to the TAG compositional changes caused by interesterification. According to previous studies, non-specific lipases were reported to cause randomization of fatty acids within and in between TAG molecules ${ }^{22)}$ that affect their thermal characteristics. Generally, TAG molecules with higher degree of saturation are found to melt at higher temperature while those with lower degree of saturation melt at lower temperatures.

\subsection{Fatty acid composition}

Fatty acid composition of LD, EF, CaO, EF-4 and its interesterified blends were presented in Table 1. CaO sample predominantly consisted of oleic acid $(61.5 \%)$ while the amounts of palmitic and stearic acids were $4.59 \%$ and $1.73 \%$, respectively. When compared to $\mathrm{CaO}, \mathrm{LD}$ possessed higher levels of palmitic (23.78\%) and stearic (12.96\%) acids and lower level of oleic acid $(40.17 \%)$. With the addition of $40 \% \mathrm{EF}$ into $\mathrm{CaO}$, the fatty acid composition of the original sample changed remarkably (Table 1). Although oleic was the most dominant fatty acid of EF-4, stearic was found to become the second most abundant fatty acid. This was because EF was a highly saturated fat having high amount of stearic (48\%) and palmitic (16.1\%) acids. After enzymatic interesterification of EF-4 to different time intervals, there were no remarkable changes in the proportional distribution of different fatty acids. It is because interesterification of fats by non-specific lipases does not usually bring significant changes in the fatty acid composition of interesterified fat blends ${ }^{23)}$.

\subsection{TAG composition}

The TAG profiles of LD, EF, CaO, EF-4 and its interesterified blends are compared as shown in the Table 2. $\mathrm{CaO}$ was found to possess $86.3 \%$ of triunsaturated TAGs such as OOO, OOL and OOLn while EF was found to have higher proportion of disaturated TAG molecules such as $\operatorname{SOS}(53.1 \%), \operatorname{SPO}(36.0 \%)$ and $\mathrm{PPO}(6.6 \%)$. The physical blend EF-4 was found to have SOS $(20.6 \%)$ as the dominant TAG species followed by $\mathrm{OOO}(17.8 \%)$, SPO (14.2\%), and OOL (13.8\%). Enzymatic interesterification of fat blends usually leads to intermolecular and intramolecular rearrangement of component fatty acids ${ }^{22}$. Particularly, lipase from $C$. antartica lipase which is a non-specific enzyme has been already known for causing random redistribution of fatty acids within and between TAG molecules during interesterification ${ }^{24)}$. According to Table 2, in all three interesterified blends, there were increases in the total amounts of triunsaturated and monounsaturated TAG molecular groups with a concurrent reduction in the total proportion of disaturated TAG molecular group. For instance, increas- es in $\mathrm{OOO}$ and OOL led to increase of the total amounts of triunsaturated TAG molecular group while increases in $\mathrm{POO}$ and SOO caused the increase of the total amount of monosaturated TAG molecular group. A reduction in the total amount of disaturated TAG molecular group (39.3\% to $32.7 \%$ ) could be probably due to the decrease in the amounts of disaturated TAG species such as $\mathrm{SPO}(14.2 \%$ to $12.3 \%)$ and SOS (20.6\% to $16.8 \%)$. However, the proportional differences of various TAG molecular species present in all three interesterified fat blends [EF-1 (6h), EF-1 (12h) and EF-1(24h)] were not drastic. Thus, it could be assumed that the reaction time $6 \mathrm{~h}$ of interesterification time by Novozym 435 would be just sufficient to cause the required changes in EF-4.

\subsection{SFC profile}

The SFC profiles of LD, EF, CaO, EF-4 and its interesterified blends are compared as shown in Fig. 1 . At $0^{\circ} \mathrm{C}$, the SFC values of $\mathrm{EF}, \mathrm{LD}$ and $\mathrm{CaO}$ were $90.85 \%, 31.56 \%$, and $0.2 \%$. Overwhelmingly higher proportion of disaturated TAG molecules (95.7\%) in EF (Table 2) would make the SFC to be very high. Since LD was found to possess a considerably greater proportion of mono-unsaturated TAG molecules, it was softer in nature in comparison to EF. The SFC of EF declined dramatically as the temperature increased until $35^{\circ} \mathrm{C}$. Since the largest decline in SFC of EF occurred from $15-30^{\circ} \mathrm{C}$, TAGs in large amount would have liquefied within this temperature range ${ }^{25)}$. The $\mathrm{SFC}$ of $\mathrm{EF}$ was almost zero at the temperature range of $35-40^{\circ} \mathrm{C}$ indicating that most of the TAGs were in liquid phase. Being a liquid oil, $\mathrm{CaO}$ would not perform any solidification even at $4^{\circ} \mathrm{C}^{26)}$ because it possessed high levels of triunsaturated and monosaturated TAG molecules (Table 2). When compared to $\mathrm{CaO}, \mathrm{EF}-4$ was found to have $\mathrm{SFC}$ value of $38.9 \%$ at $0^{\circ} \mathrm{C}$ because of the significant decrease in the proportion of triunsaturated TAG molecules $(51.5 \%)$ with the concurrent increase in disaturated TAG molecules (Table 2). The SFC profile of EF-4 was found to display a pattern of change similar to $\mathrm{LD}$ at the temperature range of $0-35^{\circ} \mathrm{C}$, but the values were always higher than those of $\mathrm{LD}$.

The changes caused by interesterification in the fatty acid distributions of TAG molecules were found to reflect in the SFC of interesterified blends within the temperature range of $0-55^{\circ} \mathrm{C}$. As indicated in Fig. $1, \mathrm{SFC}$ of all three interesterified blends were lower than those of EF-4 at the temperature range of $0-35^{\circ} \mathrm{C}$. This could be due to the fact that the randomization of fatty acids in the TAG molecules by interesterification has caused enhancement in the proportions of triunsaturated and monosaturated TAGs with lower melting points (Table 2). According to Fig. 1, differences within the SFC curves of the three interesterified blends with different reaction times were minimal. Among them, the SFC values of EF-4(12h) and EF-4(24h)were 
Table 2 TAG composition of LD, CaO, EF, LD, EF-4 (EF: CaO 60:40) and its interesterified blends*.

\begin{tabular}{|c|c|c|c|c|c|c|c|c|}
\hline & ${ }^{1} \mathrm{CaO}$ & ${ }^{1} \mathrm{EF}-4$ & EF-4 (6 h) & EF-4 (12 h) & EF-4 (24 h) & & LD & ${ }^{1} \mathrm{EF}$ \\
\hline \multicolumn{9}{|c|}{ Triunsaturated } \\
\hline LnLnL & $1.3 \pm 0.0^{\mathrm{a}}$ & $0.8 \pm 0.0^{\mathrm{b}}$ & $0.4 \pm 0.02^{\mathrm{c}}$ & $0.4 \pm 0.01^{\mathrm{c}}$ & $0.3 \pm 0.1^{\mathrm{c}}$ & & - & - \\
\hline LLLn & $3.2 \pm 0.5^{\mathrm{a}}$ & $2.2 \pm 0.0^{\mathrm{b}}$ & $2.6 \pm 0.1^{\mathrm{ab}}$ & $2.3 \pm 0.2^{\mathrm{b}}$ & $2.2 \pm 0.1^{\mathrm{b}}$ & 0.9 & $\pm 0.0^{\mathrm{c}}$ & - \\
\hline LLL & $9.0 \pm 0.2^{\mathrm{a}}$ & $4.8 \pm 0.0^{\mathrm{c}}$ & $5.8 \pm 0.1^{\mathrm{b}}$ & $5.7 \pm 0.12^{\mathrm{b}}$ & $5.4 \pm 0.1^{\mathrm{b}}$ & 0.3 & $\pm 0.0^{\mathrm{d}}$ & - \\
\hline OLLn & $7.8 \pm 0.2^{\mathrm{a}}$ & $5.0 \pm 0.0^{\mathrm{b}}$ & $5.0 \pm 0.0^{\mathrm{b}}$ & $5.1 \pm 0.1^{\mathrm{bc}}$ & $4.8 \pm 0.0^{\mathrm{b}}$ & & - & - \\
\hline OOLn & $10.8 \pm 0.2^{\mathrm{a}}$ & $6.6 \pm 0.1^{\mathrm{b}}$ & $6.5 \pm 0.1^{\mathrm{b}}$ & $6.6 \pm 0.2^{\mathrm{b}}$ & $6.6 \pm 0.2^{\mathrm{b}}$ & & - & - \\
\hline OOL & $23.1 \pm 0.2^{\mathrm{a}}$ & $13.8 \pm 0.2^{\mathrm{c}}$ & $14.5 \pm 0.0^{\mathrm{b}}$ & $14.6 \pm 0.2^{b}$ & $14.5 \pm 0.2^{\mathrm{b}}$ & 6.1 & $\pm 0.0^{\mathrm{d}}$ & - \\
\hline OOO & $30.1 \pm 0.0^{\mathrm{a}}$ & $17.8 \pm 0.2^{\mathrm{c}}$ & $18.8 \pm 0.3^{\mathrm{b}}$ & $19.3 \pm 0.2^{\mathrm{b}}$ & $19.1 \pm 0.0^{\mathrm{b}}$ & 4.1 & $\pm 0.0^{\mathrm{d}}$ & - \\
\hline OOGa & $1.1 \pm 0.0^{\mathrm{a}}$ & $0.5 \pm 0.2^{\mathrm{b}}$ & $0.9 \pm 0.2^{\mathrm{ab}}$ & $0.7 \pm 0.0^{\mathrm{ab}}$ & $0.7 \pm 0.0^{\mathrm{ab}}$ & & - & - \\
\hline OLL & - & - & - & - & - & 4.40 & $0 \pm 0.04^{\mathrm{a}}$ & - \\
\hline Sub Total & $86.3 \pm 1.2^{\mathrm{a}}$ & $51.5 \pm 0.1^{\mathrm{c}}$ & $54.5 \pm 0.1^{\mathrm{b}}$ & $54.5 \pm 0.5^{\mathrm{b}}$ & $53.7 \pm 0.5^{\mathrm{b}}$ & 15.9 & $\pm 0.0^{\mathrm{d}}$ & - \\
\hline \multicolumn{9}{|c|}{ Monosaturated } \\
\hline PLLn & $0.9 \pm 0.0^{\mathrm{a}}$ & $0.1 \pm 0.0^{\mathrm{d}}$ & $0.7 \pm 0.0^{\mathrm{b}}$ & $0.6 \pm 0.0^{\mathrm{c}}$ & $0.6 \pm 0.0^{\mathrm{c}}$ & & - & - \\
\hline $\mathrm{POL} / \mathrm{SLL}$ & $5.3 \pm 0.3^{\mathrm{b}}$ & $3.1 \pm 0.0^{\mathrm{d}}$ & $3.9 \pm 0.3^{\mathrm{c}}$ & $3.4 \pm 0.0^{\mathrm{cd}}$ & $3.9 \pm 0.0^{c}$ & 22.6 & $\pm 0.1^{\mathrm{a}}$ & - \\
\hline $\mathrm{POO} / \mathrm{SOL}$ & $5.9 \pm 0.1^{\mathrm{b}}$ & $4.2 \pm 0.2^{\mathrm{d}}$ & $4.7 \pm 0.4^{\mathrm{cd}}$ & $4.7 \pm 0.0^{\text {cd }}$ & $5.2 \pm 0.0^{\mathrm{c}}$ & 22.1 & $\pm 0.1^{\mathrm{a}}$ & $0.2 \pm 0.1^{\mathrm{e}}$ \\
\hline SOO & $1.7 \pm 0.2^{\mathrm{b}}$ & $1.3 \pm 0.0^{\mathrm{b}}$ & $3.0 \pm 0.2^{\mathrm{ab}}$ & $2.9 \pm 0.2^{\mathrm{ab}}$ & $3.4 \pm 0.1^{\mathrm{a}}$ & 3.3 & $\pm 0.1^{\mathrm{ab}}$ & $1.0 \pm 0.1^{\mathrm{b}}$ \\
\hline PLL & - & - & - & - & - & 7.0 & $\pm 0.2^{\mathrm{a}}$ & - \\
\hline Sub Total & $13.8 \pm 0.5^{\mathrm{b}}$ & $8.6 \pm 0.1^{\mathrm{d}}$ & $12.3 \pm 0.0^{\mathrm{bc}}$ & $11.6 \pm 0.2^{\mathrm{c}}$ & $13.1 \pm 0.2^{\mathrm{bc}}$ & 55.0 & $\pm 0.47^{\mathrm{a}}$ & $1.2 \pm 0.9^{\mathrm{e}}$ \\
\hline \multicolumn{9}{|c|}{ Disaturated } \\
\hline PSLn & $0.2 \pm 0.1^{\mathrm{a}}$ & $0.2 \pm 0.0^{\mathrm{a}}$ & $0.3 \pm 0.2^{\mathrm{a}}$ & $0.1 \pm 0.0^{\mathrm{a}}$ & $0.3 \pm 0.2^{\mathrm{a}}$ & & - & - \\
\hline SPO & - & $14.2 \pm 0.1^{\mathrm{b}}$ & $12.6 \pm 0.1^{\mathrm{c}}$ & $12.8 \pm 0.2^{\mathrm{c}}$ & $12.3 \pm 0.1^{\mathrm{c}}$ & 14.3 & $\pm 0.2^{\mathrm{b}}$ & $36.0 \pm 0.2^{\mathrm{a}}$ \\
\hline SOS & - & $20.6 \pm 0.3^{b}$ & $16.8 \pm 0.2^{\mathrm{c}}$ & $17.2 \pm 0.1^{\mathrm{c}}$ & $16.8 \pm 0.1^{\mathrm{c}}$ & 1.0 & $\pm 0.1^{\mathrm{d}}$ & $53.1 \pm 0.8^{\mathrm{a}}$ \\
\hline PPL & - & - & - & - & - & 3.1 & $\pm 0.1^{\mathrm{a}}$ & - \\
\hline PPO & $0.2 \pm 0.0^{\mathrm{d}}$ & $3.0 \pm 0.08^{\mathrm{c}}$ & $2.4 \pm 0.4^{\mathrm{c}}$ & $2.6 \pm 0.1^{\mathrm{c}}$ & $2.5 \pm 0.0^{c}$ & 8.5 & $\pm 0.4^{\mathrm{a}}$ & $6.6 \pm 0.0^{b}$ \\
\hline SOA & - & $1.5 \pm 0.1^{\mathrm{a}}$ & $0.9 \pm 0.0^{\mathrm{b}}$ & $1.0 \pm 0.0^{\mathrm{b}}$ & $0.9 \pm 0.1^{\mathrm{b}}$ & & - & - \\
\hline Sub Total & $0.4 \pm 0.1^{\mathrm{e}}$ & $39.3 \pm 0.2^{b}$ & $32.9 \pm 0.3^{c}$ & $33.6 \pm 0.2^{c}$ & $32.7 \pm 0.3^{c}$ & 26.9 & $\pm 0.1^{\mathrm{d}}$ & $95.7 \pm 0.6^{\mathrm{a}}$ \\
\hline \multicolumn{9}{|c|}{ Trisaturated } \\
\hline РPP & - & - & - & - & - & 0.5 & $\pm 0.1^{\mathrm{a}}$ & - \\
\hline PPS & - & $0.2 \pm 0.0^{b}$ & - & - & - & 0.8 & $\pm 0.1^{\mathrm{a}}$ & - \\
\hline SSS & - & $0.2 \pm 0.0^{b}$ & - & - & - & 1.0 & $\pm 0.1^{\mathrm{a}}$ & - \\
\hline Sub Total & - & $0.4 \pm 0.0^{b}$ & - & - & - & 2.2 & $\pm 0.0^{\mathrm{a}}$ & - \\
\hline UK & - & $0.3 \pm 0.0^{\mathrm{b}}$ & $0.4 \pm 0.2^{\mathrm{b}}$ & $0.3 \pm 0.1^{\mathrm{b}}$ & $0.5 \pm 0.0^{b}$ & & - & $3.1 \pm 0.3^{\mathrm{a}}$ \\
\hline
\end{tabular}

*Each value in the table represents the mean of three replicates. Means within each row bearing different superscripts are significantly $(\mathrm{p}<0.05)$ different. ${ }^{1}$ Nur Illiyin et al. (2013).

$O$ oleic, $P$ palmitic, $L$ linoleic, $L n$ Linolenic, $S$ Stearic, $G a$ Gadoliec, $A$ Arachidic, $U K$ unknown $C a O$ Canola oil, $L D$ Lard, $E F-440 \%$ of physical blend, EF-4 $(6 \mathrm{H}) 40 \%$ of enzymatic blend with treatment time of 6 hours, $E F-4(12 \mathrm{H}) 40 \%$ of enzymatic blend with treatment time of 12 hours, $E F-4(24 \mathrm{H}) 40 \%$ of enzymatic blend with treatment time of 24 hours, $E F$-Engkabang fat

almost similar to those of LD within the temperatures ranges of $0-20^{\circ} \mathrm{C}$. Furthermore, the $\mathrm{SFC}$ values of all three interesterified blends were found to be similar to those of $\mathrm{LD}$ at the temperature range of $30-40^{\circ} \mathrm{C}$.

\subsection{Polymorphism}

The diffractogram of LD, EF, EF-4 and its interesterified blends are compared in Fig. 2 . LD displayed both $\beta$ - and $\beta$ ' -forms of polymorphisms of which $\beta$ 'polymorph was dominant. The occurrence of TAG molecular species, namely 


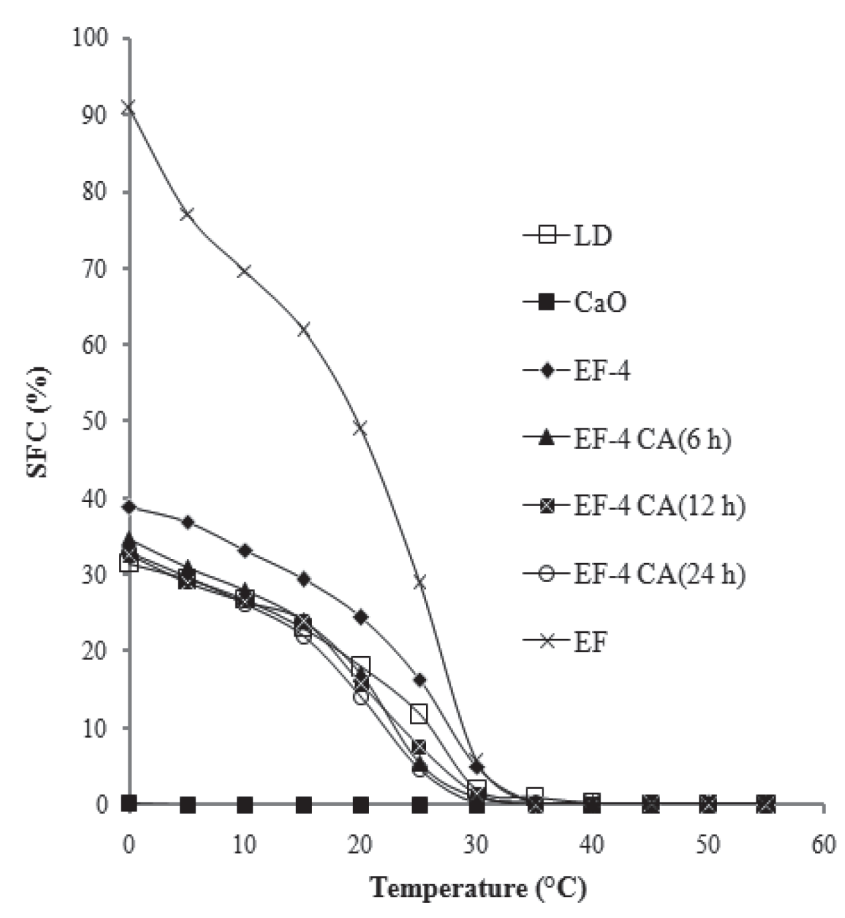

Fig. 1 Solid fat content (SFC) of lard (LD), canola oil $(\mathrm{CaO})$, engkabang fat $(\mathrm{EF})$, and interesterified blends of engkabang-canola oil (EF : $\mathrm{CaO}=40: 60$ ) using $\mathrm{C}$. antartica lipase.

Abbreviations: EF-4 40\% of physical blend, $E F-4(6 h) 40 \%$ of enzymatic blend with treatment time of 6 hours, $E F-4$ (12 h) $40 \%$ of enzymatic blend with treatment time of 12 hours, $E F-4$ (24 h) $40 \%$ of enzymatic blend with treatment time of 24 hours.

SPO and PPO in higher amounts (22\%) (Table 2) is attributed as an important factor for the polymorphic behaviour of LD. According to Timms ${ }^{27}$, presence of SPO in higher proportion could contribute to the $\beta^{\prime}$ polymorphic form in LD. Further, the crystallization process and treatment applied could crystallize LD either $\beta^{\prime}$ polymorph in rapid crystallization or both $\beta^{\prime}$ and $\beta$ polymorph in slow crystallization. As LD In this experiment experienced a temperature change from $70^{\circ} \mathrm{C}$ to $4^{\circ} \mathrm{C}$, the crystallization process would occur more effectively ${ }^{28}$. When the crystallization temperature decreases, the rate of nuclei formation becomes rapid causing the formation of large amount of nuclei leading to smaller crystals. On the other hand, EF was found to exhibit $\beta$ polymorphic form where there was a sharp peak at around $4.6 \AA$. As it was explained previous$\mathrm{ly}^{11}$, the $\beta$ polymorphism of $\mathrm{EF}$ is due to the presence of TAG species such as SOS (Table 2). There was no other polymorph identified for EF since the peaks do not emerge at any short spacing that exhibiting any polymorphic properties.

According to Fig. 2, physical blend EF-4 displayed both

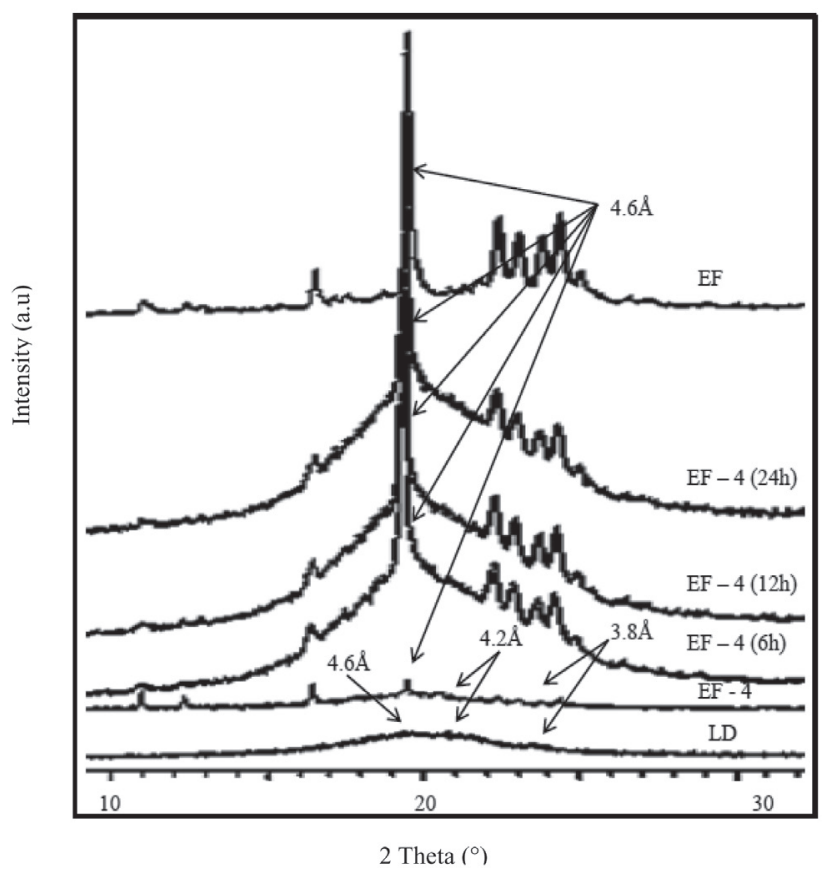

Fig. 2 WAXD-pattern of lard (LD), engkabang fat (EF), and interesterified blends of engkabang-canola oil (EF: $\mathrm{CaO}=40: 60)$ using $C$. antartica lipase. Abbreviations: See Fig. 1

$\beta$ polymorphic form at $4.6 \AA$ and $\beta$ ' polymorphic form at 3.8 $\AA$ and $4.2 \AA$, which were similar to the polymorphic behaviour of LD. This might be due to the increased proportion of disaturated TAG molecular species such as PPO and SPO in the blend. Generally, the increase in the total proportion of disaturated TAG molecular group lead to higher rate of nuclei formation and thus, large amount of small crystals were tended to form when the crystallization temperature was decreased from $70^{\circ} \mathrm{C}$ to $4{ }^{\circ} \mathrm{C}$. Ribeiro et al. ${ }^{20)}$ explained that the crystal habit of fat blends could be modified through interesterification. In this experiment, all interesterified blends exhibited only a strong peak at $4.6 \AA$ as compared to EF-4. It could be due to changes taking place in the amount in TAG molecular species where it could be observed clearly monosaturated and disaturated TAG molecular groups were affected after interesterification. According to Reshma et $a l .^{23)}$, fatty acid combinations in TAG could influence the formation of a specific polymorphic phase in a TAG multi-component system.

\subsection{Thermal characteristics by DSC}

An overlay of the DSC melting curve of $\mathrm{LD}, \mathrm{CaO}, \mathrm{EF}$, EF-4 and its interesterified blends are presented in Fig. 3. LD was found to display two major endothermic thermal transitions at $-1.96^{\circ} \mathrm{C}\left(\mathrm{a}_{2}\right)$ and $26.26^{\circ} \mathrm{C}\left(\mathrm{a}_{4}\right)$. EF displayed a melting curve comprised of a major thermal transition at $26.60^{\circ} \mathrm{C}\left(\mathrm{g}_{3}\right)$ and three minor transitions at $-7.2^{\circ} \mathrm{C}\left(\mathrm{g}_{1}\right)$, $11.8^{\circ} \mathrm{C}\left(\mathrm{g}_{2}\right)$ and $31.2^{\circ} \mathrm{C}\left(\mathrm{g}_{4}\right)$. The thermal curve of $\mathrm{CaO}$ pos- 


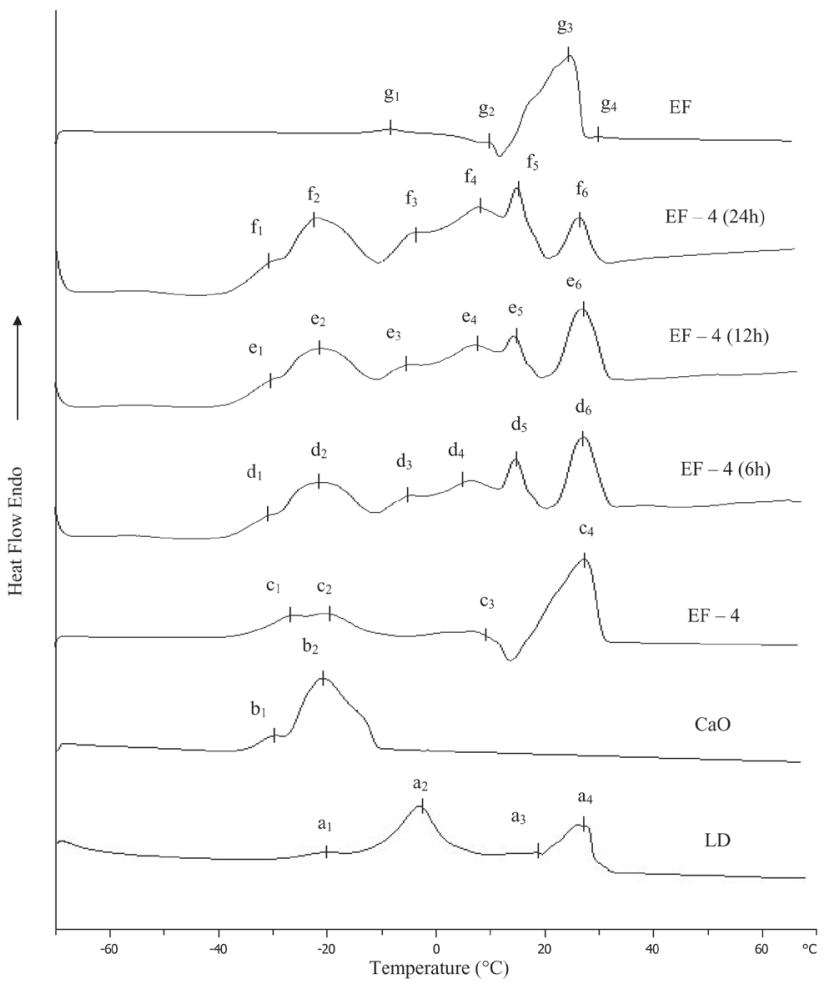

Fig. 3 Heating curves of lard (LD), canola oil $(\mathrm{CaO})$, engkabang fat (EF), and interesterified blends of engkabang-canola oil ( $\mathrm{EF}: \mathrm{CaO}=40: 60)$ using $C$. antartica lipase.

sessed a major transition at $-19.78^{\circ} \mathrm{C}\left(\mathrm{b}_{2}\right)$ with a shoulder peak at $-29.59^{\circ} \mathrm{C}\left(b_{1}\right)$. EF-4, the blend obtained by mixing $\mathrm{EF}$ with $\mathrm{CaO}$ was found to display a major transition at $29.66^{\circ} \mathrm{C}\left(\mathrm{c}_{4}\right)$ and three minor transitions at $-25.70^{\circ} \mathrm{C}\left(\mathrm{c}_{1}\right)$, $-17.53^{\circ} \mathrm{C}\left(\mathrm{c}_{2}\right)$ and $9.57^{\circ} \mathrm{C}\left(\mathrm{c}_{3}\right)$. When compared to $\mathrm{CaO}$, nature of thermal profile displayed by EF-4 could be justified by its TAG composition. The melting curves of the interesterified blends of EF-4 at three different reaction intervals showed significant variation from that of EF-4 with respect to thermal transitions as well as associated DSC parameters. For instance, all three interesterified blends were found to exhibit six thermal transitions while physical blend EF-4 had only four them. As a noteworthy feature, the major thermal transition of EF-4 at $29.66^{\circ} \mathrm{C}\left(\mathrm{c}_{4}\right)$ was found to decrease in size with the increasing interesterification time. In addition, the position of this thermal transition also get slightly shifted after interesterification of $6 \mathrm{~h}$ $\left(\mathrm{d}_{6}, 29.72^{\circ} \mathrm{C}\right), 12 \mathrm{~h}\left(\mathrm{e}_{6}, 29.25^{\circ} \mathrm{C}\right)$ and $24 \mathrm{~h}\left(\mathrm{f}_{6}, 28.90^{\circ} \mathrm{C}\right)$. Meanwhile, the minor thermal transition of EF-4 at $-17.53^{\circ} \mathrm{C}\left(\mathrm{c}_{2}\right)$ was found to increase in size with the increasing interesterification time. The position of this thermal transition also get slightly shifted after interesterification of $6 \mathrm{~h}\left(\mathrm{~d}_{2},-20.43^{\circ} \mathrm{C}\right), 12 \mathrm{~h}\left(\mathrm{e}_{2},-20.57^{\circ} \mathrm{C}\right)$ and $24 \mathrm{~h}$ $\left(\mathrm{f}_{2},-20.02^{\circ} \mathrm{C}\right)$. These changes in DSC variables could be attributed to the decrease in total amount of disaturated
TAG molecular group with the concurrent increases in the total amount of triunsaturated and monosaturated TAG molecular groups (Table 2). In comparison to LD, these interesterfied fat blends showed only few similarities in thermal profile. For instance, the peak $\mathrm{f}_{3}$ of EF-4 $(24 \mathrm{~h})$ at $-2.39^{\circ} \mathrm{C}$ was found become closer to peak $\mathrm{a}_{2}$ of $\mathrm{LD}$ which was at -1.96 C. Apart from that, the peak $\mathrm{e}_{6}$ of EF-4 $(12 \mathrm{~h})$ at $26.25^{\circ} \mathrm{C}$ was similar to the peak of $\mathrm{LD}$ at $26.26\left(\mathrm{a}_{4}\right)$.

\section{CONCLUSIONS}

This study demonstrated the feasibility of producing a fat blend to imitate some of the thermal properties of $\mathrm{LD}$ by interesterification of $\mathrm{EF}-\mathrm{CaO}$ mixture using $C$. antarti$c a$ lipase. SMP of the fat blend interesterified for $6 \mathrm{~h}$ was closely similar to that of LD. SFC values of fat blends interesterified for 12 and $24 \mathrm{~h}$ were found to become equal to those of $\mathrm{LD}$ at the temperature range of 0 to $20^{\circ} \mathrm{C}$. Similar to $\mathrm{LD}$, all three interesterified blends had their $\mathrm{SFC}$ values approaching zero at the temperature range $30-40^{\circ} \mathrm{C}$. According to DSC analysis, there were fewer similarities between LD and interesterified fat blends. Although physical blend EF-4 displayed polymorphic behaviour similar to $\mathrm{LD}$, this feature did not appear to be seen in any of the interesterified blends. Further studies would be required to evaluate the performance of the fat blends in bakery products, which often use shortening as fat ingredient.

\section{REFERENCE}

1) Meyer-Rochow, V. B. Food taboos: their origins and purposes. J. Ethnobiol. Ethnomed. 5, 18-23 (2009).

2) Regenstein, J. M.; Chaudry, M. M.; Regenstein, C. E. The kosher and halal food laws. Cpmpr. Rev. Food Sci. Food Safety 2, 111-127(2003).

3) Moore, J. R. Swine production: a global perspective. http://en.engormix.com/MA-pig-industry/articles/ swine-production-global-perspective (accessed 23 July 2013)

4) Haas, M. J. Animal fats. In: Bailey's industrial oil and fat products (Shahidi, F. ed.). Vol. $6,6^{\text {th }}$ edn. New Jersey: John Wiley \& Sons Inc, Chapter 5 (2005).

5) Ockerman, H. W.; Basu, L. Edible Rendering-Rendered Products For Human Use. In: Essential Rendering (Meeker, D. L. ed.) . National Renderers Association. Virginia. Chapter 6 (2006).

6) Ospina-E, J. C.; Cruz-S, A.; Pérez-Álvarez, J.; Fernández-López, J. Development of combinations of chemically modified vegetable oils as pork backfat substitutes in sausages formulation. Meat Sci. 84, 491-497 (2010).

7) Delgado-Pado, G; Cofrades, S.; Rodríguez-Salas, L.; Ji- 
ménez-Colmenero, F. A healthier oil combination and konjac gel as functional ingredients in low-fat pork liver pâté. Meat Sci. 88, 241-248(2011).

8) Rodriguez-Carpena, J. G.; Morcuende, D.; Estevez, M. Partial Replacement of Pork Back-Fat by Vegetable Oils in Burger Patties: Effect on Oxidative Stability and Texture and Color Changes during Cooking and Chilled Storage. J. Food Sci. 6, 1025-1031 (2011).

9) Choi, Y. S.; Choi, J. H.; Han, D. J.; Kim, H. Y.; Lee, M. A.; Jeong, J. Y.; Chung, H. J.; Kim, C. J. Effects of replacing pork back fat with vegetable oils and rice bran fiber on the quality of reduced-fat frankfurters. Meat Sci. 84, 557-563(2010).

10) Muguerza, E.; Ansorena, D.; Astiasaran, I. Improvement of nutritional properties of Chorizo de Pamplona by replacement of pork backfat with soy oil. Meat Sci. 65, 1361-1367 (2003).

11） Nur Illiyin, M. R.; Marikkar, J. M. N.; Shuhaimi, M.; Mahiran, B.; Miskandar, M. S. A comparison of the thermo physical behaviour of engkabang (Shorea macrophylla) seed fat-canola oil blends and lard. J. Am. Oil Chem. Soc. 90, 1485- 1493 (2013).

12) Seriburi, V.; Akoh, C. C. Enzymatic interesterification of lard and high-oleic sunflower oil with Candida antarctica lipase to produce plastic fats. J. Am. Oil Chem. Soc., 75, 1339-1345(1998).

13） Marikkar, J. M. N.; Lai, O. M.; Ghazali, H. M.; Che Man, Y. B. Detection of lard and randomized lard as adulterants in refined-bleached-deodorized palm oil by differential scanning calorimetry. J. Am. Oil Chem. Soc. 78, 1113-1119(2001).

14) AOAC. Official methods of AOAC international, $18^{\text {th }}$ edn. Association of Official Analytical Chemist Washington, DC. (2007).

15) Farmani, J.; Hamedi, M.; Safari, M.; Madadlou, A. Trans-free Iranian vanaspati through enzymatic and chemical transesterification of triple blends of fully hydrogenated soybean, rapeseed and sunflower oils. Food Chem. 102, 827-833 (2007).

16) AOCS Official and tentative methods of the American Oil Chemists' Society, 5th edn. Champaign, USA. (1999).

17) PORIM Test Methods Palm oil Research Institute of Malaysia. Kuala Lumpur, pp 83-91. (1995).

18) Yanty, N. A. M.; Marikkar, J. M. N.; Che Man, Y. B.;
Long, K. Composition and thermal analysis of lard stearin and lard olein. J Oleo Sci. 60, 333-338(2011).

19) Marikkar, J. M. N.; Ghazali, H. M.; Che Man, Y. B.; Peiris, T. S. G.; Lai, O. M. Distinguishing lard from other animal fats in admixtures of some vegetable oils using liquid chromatographic data coupled with multivariate data analysis. Food Chem. 91, 5-14(2005).

20) Ribeiro, A. P. B.; Basso, R. C.; Grimaldi, R., Gioielli, L. A.; Gonçalves, L. A. G. Instrumental methods for the evaluation of interesterified fats. Food Anal. Meth. 2, 282-302 (2009).

21) D’Souza, L.; deMan, L.; deMan, J. M. Chemical and physical properties of the high melting glyceride fractions of commercial margarine. J. Am. Oil Chem. Soc. 68, 153-162 (1991).

22) Willis, W. M.; Marangoni, A. G. Enzymatic Interesterification. In: Food Lipids. Chemistry, nutrition, and biotechnology (ed. Akoh, C. C, Min, D. B.) Marcel Dekker, Inc. Chapter 25 (1998).

23) Reshma, M. V.; Saritha, S. S.; Balachandran, C.; Arumughan, C. Lipase catalysed interesterification of palm stearin and rice bran oil blends for preparation of zero trans shortening with bioactive phytochemicals. Biores. Tech. 99, 5011-5019(2008).

24) Criado, M.; Hernandez-Martin, E.; Lopez-Hernandez, A.; Otero, C. Enzymaticinteresterification of extra virgin olive oil with a fully hydrogenated fat: characterization of the reaction and its products. J. Am. Oil Chem. Soc. 84, 717-726 (2007)

25) Dian, N. L. H. M.; Sundram, K.; Idris, N. A. Effect of chemical interesterification on triacylglycerol and solid fat contents of palm stearin, sunflower oil and palm kernel olein blends. Eur. J. Lipid Sci. Tech. 109, 147156 (2007).

26) Przybylski, R.; Mag, T.; Eskin, N. A. M.; McDonald, B. E. Canola Oil. In: Bailey's industrial oil and fat products (Shahidi, F. ed.). Vol. 6, $6^{\text {th }}$ edn. New Jersey: John Wiley \& Sons Inc, Chapter 2 (2005).

27) Timms, R. E. Phase behaviour of fats and their mixtures. Prog. Lipid Res. 23, 1-38(1984).

28) Herrera, M. L.; Falabella, C.; Melgarejo, M.; Anon, M. C. Isothermal crystallization of hydrogenated sunflower oil: I-Nucleation. J. Am. Oil Chem. Soc. 75, 12731280 (1998). 